\title{
How does a primary school organize outdoor swimming and water safety lessons?
}

\author{
Torbjørn Lundhaug^ \& Hege Randi Eriksen \\ Western Norway University of Applied Sciences, Norway
}

\begin{abstract}
The main purpose of this study was to explore how a primary school organized a week with outdoor education, and especially what characterized the outdoor swimming and water safety (SWS)lessons. The SWS-lessons were part of the physical education (PE) program. Two teachers and one headmaster from a primary school participated in the study. Four days of video observation of SWS-lessons were used in photo-elicitation interviews with teachers and the headmaster. The findings revealed that the headmaster highly prioritized the outdoor education practice in this school and that the teachers' colleagues showed great eagerness to cooperate and prioritize these lessons. The week's organization was characterized by collaborating management, and the outdoor SWS-lessons were characterized by experiential learning, challenge by choice, and risk awareness. The outdoor education practice corresponded well with the Norwegian curriculum goals about learning to be safe in, on, and around water.
\end{abstract}

Keywords: Outdoor education; swimming and water safety; adventurous activities; teachers experiences

Received: March, 2021; Accepted: November, 2021; Published: January, 2022

\section{Introduction}

Drowning is the third leading cause of death for children aged 5-14 years worldwide (World Health Organization, 2006). In addition, for every child who dies from drowning in the US, another eight receive emergency department care for nonfatal submersion injuries (Centers for Disease Control and Prevention, 2021). The learning arena outside in lakes, rivers, and the sea is authentic and where most drowning accidents happen in Norway (Norwegian Society for Sea Rescue, 2020) and the UK (National Water Safety Forum, 2019). In low- and middle-income countries, children are more likely to drown in nearby water bodies during daily activities (Linnan et al., 2007). However, in the US, more children aged 0-4 years drowned in residential pools than

^Correspondence: Torbjørn Lundhaug, e-mail: tolu@hvl.no

(C) 2022 T. Lundhaug \& H. R. Eriksen. This is an Open Access article distributed under the terms of the Creative Commons Attribution 4.0 International License (https://creativecommons.org/licenses/BY/4.0/), allowing third parties to copy and redistribute the material in any medium or format and to remix, transform, and build upon the material for any purpose, even commercially, provided the original work is properly cited and states its license.

Citation: T. Lundhaug $\mathcal{E}$ H. R. Eriksen. "How does a primary school organize outdoor swimming and water safety lessons?" fournal for Research in Arts and Sports Education, Special issue: Friluftsliv, dannelse, laring og didaktikk, 
in natural water bodies (World Health Organization, 2006). While in Norway, children aged 1 to 14 are most likely to drown while swimming in natural water bodies or after falling into the sea or river (Norwegian Society for Sea Rescue \& Retriever, 2020). Drowning rates are highest in early childhood and decrease rapidly in middle childhood, and in low- and middle-income countries, the rates further fall in adolescence (Linnan et al., 2012). However, in many high-income countries, they rise in adolescence because of recreational drownings in lakes and rivers (Peden et al., 2008).

Interventions to prevent drowning range from community-based solutions to effective national policies and water safety legislation (World Health Organization, 2017). There is little conclusive evidence that participation in swimming lessons decreases the risk of drowning in high-income countries (Stallman et al., 2013). However, some case-control studies show that naturally acquired swimming ability or receiving swimming lessons may reduce the risk of drowning (Brenner et al., 2009; Yang et al., 2007). The SwimSafe Cohort Trial (Rahman et al., 2012) showed an actual reduction in fatal drowning among schoolchildren in rural Bangladesh. A review of drowning prevention interventions revealed an overreliance on education and information as a strategy to prevent drowning (Leavy et al., 2016). Despite limited evidence that teaching children to swim will protect them from drowning, it has been suggested that teaching school-aged children swimming and water safety skills are essential to preventing drowning (Kjendlie et al., 2013; World Health Organization, 2017). In WHO's guidelines to prevent drowning, selecting training sites near distance to where the children lived was highlighted as an essential factor when teaching school-aged children swimming and water safety skills (World Health Organization, 2017). Improving pupils' swimming and water safety skills outside in cold water may be an excellent choice to prevent children from later drowning accidents (Gjølme \& Grydeland, 2021; Stallman et al., 2017). It has been argued that there is a need for research on water survival competencies in open and closed water environments (Stallman et al., 2017). In Norway, SWS lessons are part of the physical education (PE) curriculum, where the goal is to teach the pupils to be competent swimmers, learn self-rescue and lifesaving skills. Regardless of this, only $2 \%$ of Norwegian schools practice swimming and life rescuing outside in natural environments (Waagene et al., 2018). However, this study was completed when outdoor swimming and water safety was not explicit in the physical education curriculum.

Teaching practices in primary schools include sporadic outdoor education (Holthe et al., 2015). This pedagogical approach is used to enrich learning, enhance school engagement, and improve pupil health and well-being (Marchant et al., 2019). Outdoor learning involves curriculum-based education for pupils aged 6-16, and the teaching takes place outside of the classroom (Jordet, 2007). The outdoor activities' pedagogical approach relates to experiential learning, challenge by choice, and risk management (Williams \& Wainwright, 2020). Norway has strong cultural ties to nature, and the concept of "friluftsliv", meaning outdoor life. Teaching local friluftsliv 
traditions is a competence aim in physical education where the goal is to raise environmental awareness through joyful and playful experiences in nature.

The position of friluftsliv is vital in the national curriculum, and it is well established to combine the cultural tradition of friluftsliv with outdoor SWS-learning. However, even though the scope of friluftsliv is satisfactory among the youngest in primary school, it seems that the schools practice friluftsliv in a minor degree from grade 5 and up (Leirhaug \& Arnesen, 2016). In Norway, primary schools have an annual average of five days of friluftsliv and outdoor activities within physical education during the first years (Leirhaug \& Arnesen, 2016), and few schools practice outdoor SWS-lessons. The aim of this study was to explore how one primary school organized five days of outdoor education with an emphasis on the organization and characteristics of the outdoor swimming and water safety lessons.

\section{Method}

Design

A case study was done since few studies and practices show how to organize outdoor swimming and water safety in primary schools. A case study is suitable for smaller-scale studies seeking insight into a school practice through subjective experiences (Postholm, 2019).

\section{Setting}

The school arranged one week with outdoor education (OE-week) in the autumn, where all the pupils from $3^{\text {rd }}$ to $6^{\text {th }}$ grade participated in the same program. The subjects taught that week were physical education, arts and crafts, mathematics, food and health, and natural science. In addition to the different topics, the pupils participated in fishing trips and workplace visits. All the teaching took place in the school's local environment, and the SWS-lessons were conducted at a nearby beach within walking distance from the school.

\section{Recruitment and sample}

Information about the project and an invitation to participate were sent to schools recommended by peers. Two classroom teachers and one headmaster participated in the study. Herman (fictive name) was both the classroom teacher and the physical education (PE) teacher. Besides, he was an experienced swimming coach. Most of the pupils had participated in swimming courses in their spare time with Herman as their coach. He had also been their teacher in previous SWS-lessons. Herman was responsible for all the SWS-lessons during the week of outdoor education. Wendy (fictive name) was also a classroom teacher and was responsible for arts and crafts and mathematics during the week of outdoor education. She participated in all workshops that week. The headmaster coordinated the classes and teachers during the week. All the teachers had the life rescue certificate. 


\section{T. Lundhaug \& H. R. Eriksen}

\section{Data collection}

We used four days of video observation and photo-elicitation interviews (PEI) to inspire the teachers and the headmaster to reflect on their teaching experiences from the outdoor swimming lessons (Liebenberg et al., 2014; Torre \& Murphy, 2015). All swimming lessons were video recorded using hand-held waterproof action cameras, and the video recordings were reviewed and edited before the interviews. According to the research questions, four to five screenshots from the video recordings with relevant episodes were selected and presented during the interviews. We used PEI to empower the research participants and inspire them to express their meanings and thoughts in specific teaching situations. Using PEI, we asked open-ended questions to see the school practice through the teachers' and headmaster's eyes.

The interview guide was based on the didactical relationship model by Hiim and Hippe (2009), a model suitable for outdoor education under unpredictable and complex conditions. The main topics of the interview guide were: learning goals, learning process (i.e., the teacher's role and the teaching approach), content, learning conditions, setting (including possible dangerous factors), and assessment.

\section{Data analysis}

Interpretative phenomenological analysis was conducted to prioritize the participants' experience (Smith et al., 2009). Every day, one of the authors and one research assistant watched the videos recorded that day. First, segments that contained relevant data for learning goals, context, learning activities, safety issues, and learning styles were identified. In the next step, four to five video segments were selected based on specific events or moments with experiential learning, challenge by choice, or risk awareness. Screenshots from these video segments were later used in the interviews with the teachers.

Transcripts from the interviews were independently coded and compared by the researcher and the research assistant using the computer software Nvivo 10. Themes were created inductively and deductively related to the pedagogical framework of outdoor activities (Williams \& Wainwright, 2020). The researcher and assistant discussed unique and overlapping themes. Saturation was decided to be reached when no additional themes were discovered in the analysis.

\section{Ethics}

The Data Protection Services at the Norwegian Centre for Research Data approved the study. All participants received oral and written information about the study and gave written consent. All personal information was treated confidentially, and data was stored encrypted. The names of the teachers used in this article are fictive.

\section{Results}

The interviews revealed several challenges in planning a school week with outdoor SWS-lessons. It required logistics, support from management, available resources, and 
personal commitment to teaching outdoors. The results are presented as four main themes; collaborating management, experiential learning, challenge by choice, and risk awareness. Quotes are used to illustrate and validate the participants' meanings.

\section{The program of the outdoor SWS-lessons}

The teachers had made a campsite by the beach with a campfire and tents to change to wetsuits. The food and health lessons took place at the campsite, and this was also a meeting point when the classes would switch to new activities and the place for having lunch together. They restricted the swimming area by placing three balloons anchored with a stone to the bottom. The balloons were 10-15 meters from the shore, and the depth was about $120 \mathrm{~cm}$. The pupils used wetsuits but not a personal flotation device. There was one teacher in the water together with groups of 7-10 pupils. At least one more teacher was onshore as a guard. The teachers stated in the interview that they had the necessary competence and equipment to conduct the outdoor SWS-lessons and claimed that it was realistic for many more teachers to implement a similar swimming and water safety practice in their primary schools. Table 1 describes the program of the outdoor SWS-lessons during four days. The outdoor SWS-lessons were based on the national curriculum goals (KRO01-05) about learning to be safe in, on, and near water (Norwegian Directorate for Education and Training, 2019). There are different learning goals in the curriculum between 4 th and 6th grade (KRO01-05). However, the pupils in this study were organized and taught the same way with the same learning goals despite different goals in the curriculum.

Table 1. The program for four days with outdoor SWS-lessons

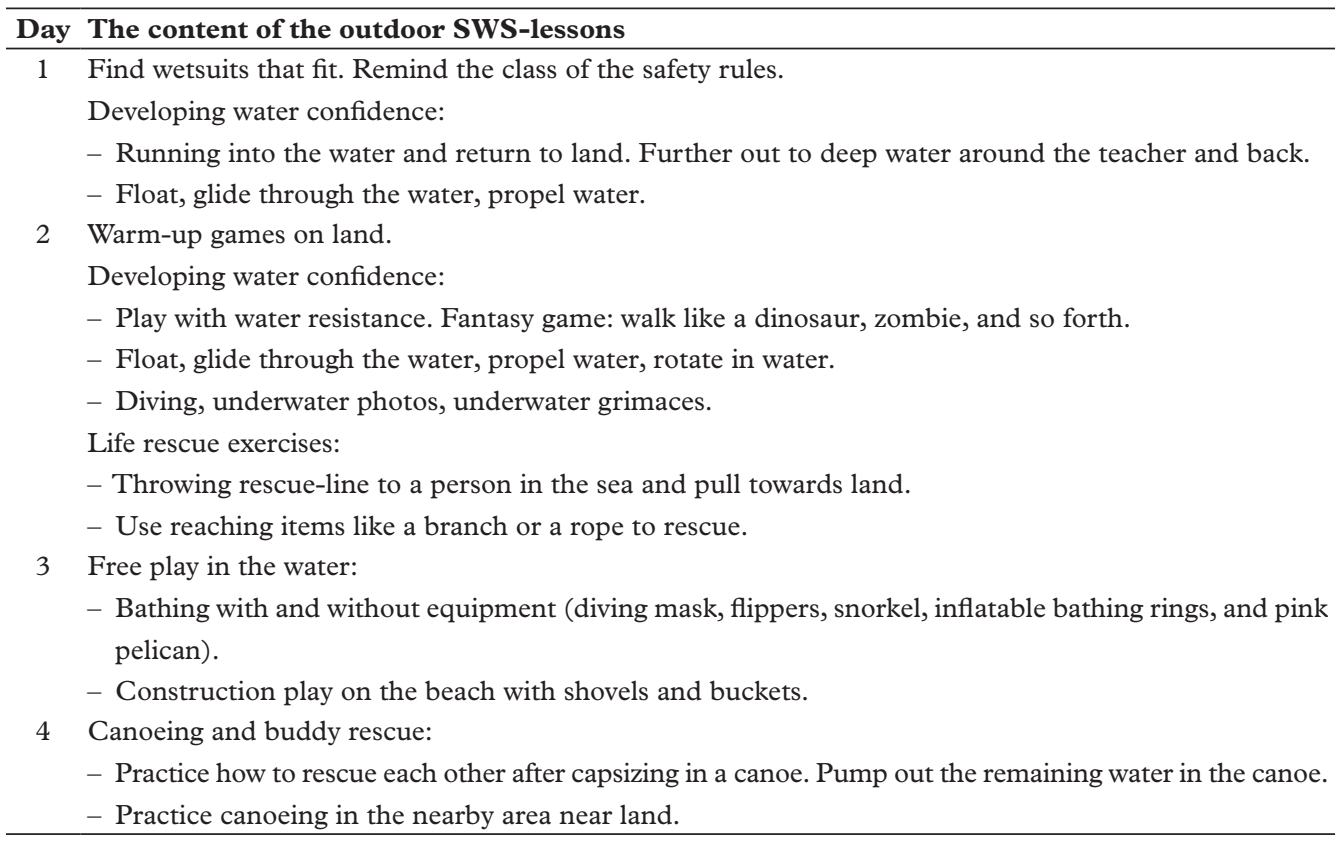


Video observations showed that the teacher adhered to the program, with minor adjustments related to the weather situation and the group context. The teacher gave a short introduction to the learning activities. He was positioned out in the water and facing the land. In that way, he watched the pupils moving from land, out in the water and returning to land. He always had visual contact with the pupils and stayed closed to them, with a maximum distance of 10 meters. The pupils were focused on the learning activities, and the teacher had their attention most of the time. The learning activities consisted of breath control, water orientation through rolling from front to back/back to front, turning in different directions, diving and underwater swimming, safe exit from the waterbody, self-rescuing, and life rescuing of each other.

\section{Collaborating management}

Before and during the OE-week, the teachers and headmaster worked together as a team. Practical challenges were discussed and solved in collaboration. They shared teaching experience, contributed ideas, and adjusted according to weather changes, if someone was sick, and so forth. The headmaster and teachers were facing several logistics problems when organizing the OE-week. It concerned coordinating the teachers, recruiting external contributors for the local work placement, and parents or grandparents to help with fishing boats. Another challenge was coordinating the transport (primarily by walking) with pupils from one activity to another. Herman said:

In other words, the logistics problem at school is the biggest enemy. All the years I have done this, it [the outdoor learning activities] must be within walking distance from the school. [...] It becomes so resource-intensive if you must rely on renting a bus or getting parents to drive, and so forth. Therefore, the walking distance to the beach is essential.

Video observations revealed that if a class were too late for their scheduled time, it would reduce the teaching time throughout the day. In addition, there were challenges with organizing wet suits, setting up tents, and preparing a campfire. The headmaster explained that it was due to all the logistic challenges that the whole outdoor week's idea arose. The headmaster said:

At first, he [Herman] suggested that only 3rd and 4th grade should take part, but then I said [to Herman], but who will teach your class then? So then I decided that all pupils from 3rd to 6th grade should participate, to release Herman from his class since he is most motivated of the teachers in the wet element.

While the headmaster valued the outdoor SWS-lessons as an essential aim in physical education, she also acknowledged the potential benefits of the outdoor learning approach in general. She claimed that pupils who spend more time outdoors made more friends than the others. Learning outside improved attitudes to learning, triggered the pupils' curiosity, and inspired them to explore new ways of solving problems, the headmaster added. The teachers appreciated the recognition the 
headmaster gave to each member of the staff. They gave her credit for the excellent collaboration between teachers. Wendy said:

The initiative must come from management in a way. And then the headmaster has to get feedback and understanding from colleagues on why doing it $[\ldots]$ The headmaster is very passionate about Herman implementing the outdoor lifesaving lessons. It is all about management having to see that it [outdoor learning] is important.

Also, the pupils were involved in the teachers' co-creating of planning the OE-week. On the second day of the OE-week, a pupil suggested spending the night in the tents at the campsite. The weather forecast was predicting sun, no wind, and 15 degrees Celsius. Almost all the pupils supported the idea and joined the sleepover. However, it had some consequences for the daytime program. The next day the pupils were tired after staying up late and not having much sleep. Nevertheless, the teachers said the pupils learned a lot from the sleepover in the tents. They learned to plan together for the adventurous micro-expedition, like organizing the rigging of hammocks, tents, cooking on camping stoves, and open fire. Furthermore, the pupils learned collaborative management skills. Two of the teachers and the headmaster also participated in the sleepover. During the OE-week, we identified an inclusive learning community among the teachers and headmaster. Furthermore, the pupils learned collaborative management skills themselves.

\section{Experiential learning}

Playfulness, progression, and water confidence remained at the heart of the SWSlessons. The lessons usually started with running games on land. The purpose was primarily warming up and preparing for the water immersion. While the warm-up games began on land, the pupils would always eventually enter the water. In one of the fantasy games, they took on different roles like snakes, eagles, kangaroos, and dinosaurs. While playing, they ran, jumped, bent down, and "eeled" through the water. Hermann later said that:

If they play in the water, then they develop water confidence: they experience the resistance of water, they learn to move in water; to stop, to turn, and to rotate. So the pupils learn a lot from fantasy games like walking as dinosaurs, zombies, and so forth. However, if I had said, you have to walk in a specific way in the water, like going zig-zag and stuff like that, then it would take a short time, and they had finished walking.

The teacher took photos underwater to document a thrilling moment when the pupils experienced something intense and challenging. When the students hit the deepest dive, the teacher shot a picture to capture their reactions to the exciting moment. For many, the experience was complete when they got a souvenir picture after the dive. However, the picture underwater in the SWS-lesson has more learning potential than a souvenir. Herman said: 


\section{T. Lundhaug $\mathcal{E}$ H. R. Eriksen}

Some of the pupils were very careful. The more attempts they made to get a better picture, the deeper they dived. And then I realized that I had done something clever. They also got immediate feedback on their own experience, to their question: "Did I make it?"

The teacher discovered that the photos added something more to pupils' learning. The teacher's reasoning for the photo sessions focused on at least four dimensions. First, the underwater photo worked as a motivation for the pupils. The teacher taking photos encouraged the pupils to dive deeper and to stay underwater for a longer time. The second thing was that the pupils got immediate feedback on their performance by seeing the photos just after their dive. The teacher experienced that the pictures were a tool to coach the pupils to improve their diving technique. The third benefit of the photo session was that it became a practice in self-assessment. The pictures helped the pupils evaluate their learning process and find new learning tasks to develop their SWS skills. The fourth benefit was that it allowed the teacher to assess his lessons. The documentation of his teaching helped him to be critical and to improve his didactic practice.

The headmaster said that if the teaching should contribute to progress, the pupils have to get out of their comfort zone. To do so, the teachers must give the pupils space to explore at their own pace. The headmaster explained that it was essential that pupils were seen as a positive resource and that the pupils' initiative influenced planning the outdoor SWS-lessons. If the students came up with something they wanted to find out and learn more about, the teacher should try to make it easy for them to have the opportunity to do so. The headmaster said:

The teacher must show that they are interested in learning something and not knowing the facsimile. You cannot think that you should go into the classroom and have all the answers. You may have some questions and dare to say that no, I do not know, this we must find out! It would be best if you did not behave as an omniscient teacher, but rather like to research with the students where you find out things together.

\section{Challenge by choice}

One of the pupils' tasks was to start from land, swim out to the teacher, and return to land. He was standing in the deep water, and the pupils tried the task one by one. Herman guided them in floating, gliding through the water, and propelling the water. The pupils solved this task in multiple ways. The beach area was inclusive for all the pupils because of the shallow water. Herman claimed that the beach setting provided all the pupils with opportunities to challenge themself as much as they wanted. Herman said:

They will adjust the challenge by themselves, and some prefer to swim around the teacher and back until hitting bottom in the shallow water. Others prefer to get up roughly where Vilde is now [pointing at the picture at the deepest part of the swimming area]. And then they are happy. That is fine. 
Herman had marked the learning area with floating boundaries (balloons) to contain the pupils. He had chosen a strategic site placement to avoid currents and other hazards, and paid attention to tidal conditions to ensure safe depth would not be exceeded. The pupils were aware that it was inappropriate to move outside the balloons. Besides, Herman expressed that it was easier to ensure that all pupils were challenged by having a restricted area according to their skills. Herman said:

Those who are very confident will come out to the deep water and "challenge" themselves there to be under the water and to dive. This is a challenge the pupils organize by themselves, while those who need more time are inside by the water edge and can go out calmly.

\section{Risk awareness}

Herman actualizes a learning potential in the water by letting a balloon drift with the current. He attached one of the balloons to a small rock, so it floated. By releasing the balloon so that it flows freely, it floats with the current in one direction. After a while, Herman asked the pupils why one of the balloons had moved. Some pupils raised their hands and explained that it was current, while the phenomenon was utterly unknown to other pupils. The teacher related the experience of the drifting balloon to be aware of dangers at the beach. He explained the risk of swimming in water with a rip current and demonstrated how to swim out of a rip current. Herman outlined the aims in raising risk awareness:

It means that they must know where their limits go, i.e., how far can I swim? Can I handle cold water? Can I turn around? At the same time, it assesses whether it is safe to go out or not, concerning whether there are currents or waves. To be safe in the water is to be sure that I have skills that prevent me from drowning.

Herman made an ongoing assessment of the safety at the swimming location during the OE-week, especially concerning the seabed conditions. He placed the balloons to mark the area's boundary, and he searched the bottom for sharp stones, holes, or broken glass. At one time, the bottom suddenly changed drastically from one step to the next. "Then I stepped down into a small hole, and suddenly I stood with water under my arms. Then I had to limit the area and move the balloons further in." He discussed the seabed conditions with the pupils and why they sometimes needed to adjust the swimming area.

\section{Discussion}

The primary school organized a week with outdoor education, with outdoor swimming and water safety included in the physical education program. The week was characterized by collaborating management, and the outdoor swimming and water safety lessons had experiential learning, challenge by choice, and risk awareness as crucial elements. The school's headmaster highly prioritized the outdoor education 
practice, and the teachers were eager to cooperate and prioritize these lessons. The practice corresponded well with the Norwegian curriculum goals (KRO01-05) about learning to be safe in, on, and around water.

The week was characterized by collaborating management between the headmaster, teachers, and pupils. The usefulness of organizing the swimming and safety lessons during an outdoor educational week was emphasized. This was in part due to logistic challenges, and the benefit of being close to the outdoor arena was pointed out as an essential factor for success. According to WHO's guidelines, selecting training sites near distance to where children live is highlighted as a critical factor when teaching school-aged children swimming and water safety skills (World Health Organization, 2017).

The outdoor activities were organized so the pupils faced authentic situations in the outdoor learning arena and experienced sudden events with waves, cold water, and wind. There are 15 proposed water competencies related to drowning prevention (Stallman et al., 2017). In this study, the pupils practised especially 5 of the water competencies: (1) breath control competence, (2) water orientation competence (roll from front to back, back to front and turn), (3) underwater competence (surface dive and underwater swimming), (4) safe exit competence, and (5) rescue competence (recognize a drowning person and assist a drowning person safely). They seemed to gain awareness of risk assessment, and they experienced self-rescue. Improving pupils' swimming and water safety skills outside in cold water has been suggested to prevent children from later drowning accidents (Gjølme \& Grydeland, 2021; Stallman et al., 2017). Data on the effect of swimming skills (Stallman et al., 2013) show mixed results. However, exposure to authentic and unstable situations may help reproduce water safety skills more profoundly than when swimming skills are taught in calm water (Kjendlie et al., 2013). Teaching local friluftsliv-traditions is a competence aim in physical education itself. Working with risk assessment and self-rescue in swimming and water safety fits well within an outdoor activities' pedagogical approach to risk management (Williams \& Wainwright, 2020).

The teachers took precautions, thoroughly analyzed the area, found potential dangers, and discovered learning opportunities. The teachers claimed to have developed an organizational framework suitable to provide enough time to meet the aims of the outdoor SWS-lessons. The teachers' positive experience of their practice implies that school-based programs could feasibly address most of the issues for children learning to swim and be safe in, on, and around water. Other studies have shown that schoolbased programs, where school teachers are responsible for teaching SWS-skills, are beneficial since teachers trained in classroom management are skilled in avoiding disruptions while teaching (Rahman et al., 2012). According to the SwimSafe program, swimming skills should be conducted by adults trained and certified in swim teaching and maintaining concentration with groups of children (Rahman et al., 2012). The benefits of school-based training fit our findings, where the teacher kept the group focused on the teaching. 
The cultural tradition of friluftsliv and outdoor SWS is mentioned in the curriculum and can be taught together for in-depth learning, as shown in this study. Collaborative management and interdisciplinary teaching with physical education, art and crafts, mathematics, food and health and natural science contributed to the success of the outdoor education week. The choice of training/teaching sites near where pupils live is essential when teaching swimming and water safety (WHO, 2017), and having a walking distance to the beach was one success criteria in this study. Risk awareness and prevention, i.e. use of floating boundaries, minimum of two teachers, understanding and knowledge about currents, tidal conditions etc., as used in this study, is crucial in teaching SWS lessons. Pupils understanding their limits and learn how to handle cold water can prevent later drowning accidents (Gjølme \& Grydeland 2021).

It is reasonable to assume that teaching during OE-week followed a pedagogical approach with experiential learning and challenge by choice (Williams \& Wainwright, 2020). The pupils were invited to explore and complete the challenges at their own pace. When the pupils were diving and the teacher took photos underwater, the pupils revealed the richness in the learning processes. Since the SWS-lessons were organized within the OE-week, the teachers could work with learning processes for a whole week. The photo shooting on the first day was repeated the next day. The pupil's interaction with the camera, peers, and teacher encouraged creativity, improved diving skills, and made the pupils confident in the wet element. The pupils used the photos to assess their learning process. Besides, the teacher developed the photo session to reflect upon his didactic practice.

The results are based on the outdoor SWS-practice from one school and do not explain why most schools do not practice it (Waagene et al., 2018). It seems that the lack of outdoor SWS-lessons follow the same pattern as the friluftsliv learning practice in general, where it appears that the schools practice friluftsliv on a smaller scale from grade 5 and up (Leirhaug \& Arnesen, 2016). We found that organizing the SWS lessons during an OE-week was a success. Others have reported a lack of organizational framework and not enough time as barriers to meet the aims in friluftsliv (Leirhaug \& Arnesen, 2016). Most teachers reported a need for continuing education in friluftsliv, and Leirhaug \& Arnesen (2016) questioned how that could be when most teachers also said they considered their friluftsliv competence sufficient. In our study, the teachers stated that they had the necessary competence to implement outdoor SWS-lessons. The teachers had formal competence in lifesaving, and if one teacher became ill, others could step in and do the SWS-teaching. Representatives from the school were often asked to share their experience with other schools and claimed their outdoor practice was realistic to achieve for other schools.

The main teacher "Herman" was a very experienced PE teacher and a professional swim coach. Most of the pupils were good swimmers participating in swimming courses with Herman as their coach in their spare time. Therefore, it is not certain that other teachers could do the same SWS-teaching as Herman, and we 
are not confident that other pupils would respond to the $\mathrm{OE}$ week the same way as these pupils.

\section{Conclusion and implications}

Some of the critical elements for the primary school to organize a week with outdoor education were that all teachers had lifesaving certificates, local knowledge of the water location and basic friluftsliv skills. The school had bought lavvos and camping stoves and had provided wetsuits for all pupils. The teachers chose the location for the outdoor lessons in the nearby seashore area within walking distance from the school. The site was in sheltered waters, and the program took place in early autumn with summer temperatures in the air and water and minor to moderate wind. The teachers collaborated and worked cross-disciplinary throughout the whole week of outdoor education. The pupils were provided with the possibility to play and use suitable time with the learning activities.

With basic competence in friluftsliv and fundamental skills at teaching the SWSlessons, most schools can make room for this didactic practice in their schedule. There is not much need for expensive equipment, but the pupils had wetsuits, tents, campfires etc. during the OE-week. Therefore, to successfully organize outdoor SWS, there is a need for school owners to make necessary equipment available to pupils and teachers.

This study covers one week's teaching plan of one school. The number of days is similar to the average number of days of friluftsliv and outdoor activities within physical education in primary school (Leirhaug \& Arnesen, 2016). The organization and characteristics of the outdoor SWS-lessons showed that support from colleagues and management might be necessary for schools to teach outdoor SWS-lessons following the national curriculum's competence aims.

\section{Author biographies}

Torbjørn Lundhaug is a PhD candidate at the Faculty of Education, Arts and Sports, Western Norway University of Applied Sciences. He is working on his doctoral dissertation entitled "Pupils' and teachers' experiences with outdoor education in primary school».

Hege R. Eriksen is a professor at the Faculty of Education, Arts and Sports, Western Norway University of Applied Sciences.

\section{References}

Brenner, R. A., Taneja, G. S., Haynie, D. L., Trumble, A. C., Qian, C., Klinger, R. M., \& Klebanoff, M. A. (2009). Association between swimming lessons and drowning in childhood: a case-control study. Archives of Pediatrics $\mathcal{E}$ Adolescent Medicine, 163(3), 203-210. https://doi.org/10.1001/archpediatrics.2008.563 


\section{How does a primary school organize outdoor swimming and water safety lessons?}

Centers for Disease Control and Prevention. (2021). Drowning facts: Drowning prevention. https://www.cdc.gov/ homeandrecreationalsafety/water-safety/waterinjuries-factsheet.html

Gjølme, E. G., \& Grydeland, M. (2021). Utendørs svømme- og livredning. In E. G. Gjølme (Ed.), Utendørs svømme- og livredningsopplcering (pp. 15-33). Universitetsforlaget.

Holthe, A., Hallås, B. O. \& Styve, E. T. (2015). Bruk av uteskole i de praktisk-estetiske fagene på barnetrinneten casestudie. I B. O. Hallås, \& G. Karlsen (Ed.), Natur og danning. Profesjonsutøvelse, barnehage og skole. Fagbokforlaget.

Jordet, A. N. (2007). "Nermiljøet som klasserom": en undersøkelse om uteskolens didaktikk $i$ et danningsteoretisk og erfaringspedagogisk perspektiv. [Doctoral dissertation, University of Oslo]. https://brage.inn.no/inn-xmlui/ handle/11250/132008

Kjendlie, P.-L., Pedersen, T., Thoresen, T., Setlo, T., Moran, K., \& Stallman, R. K. (2013). Can you swim in waves? Children's swimming, floating, and entry skills in calm and simulated unsteady water conditions. International fournal of Aquatic Research and Education, 7(4), 301-313. https://doi.org/10.25035/ijare. 07.04 .04

Leavy, J. E., Crawford, G., Leaversuch, F., Nimmo, L., McCausland, K., \& Jancey, J. (2016). A review of drowning prevention interventions for children and young people in high, low and middle income countries. Fournal of Community Health, 41(2), 424-441. https://doi.org/10.1007/s10900-015-0105-2

Leirhaug, P. E., \& Arnesen, T. E. (2016). Friluftsliv: Et hovedområde i kroppsøvingsfaget? In A. Horgen, M. L. Fasting, T. Lundhaug, L. I. Magnussen, \& K. Østrem (Eds.), Ute (pp. 129-152). Fagbokforlaget.

Liebenberg, L., Ungar, M., \& Theron, L. (2014). Using video observation and photo elicitation interviews to understand obscured processes in the lives of youth resilience. Childhood, 21(4), 532-547. https://doi. org/10.1177/0907568213496652

Linnan, M., Giersing, M., Cox, R., Linnan, H., Williams, M. K., Voumard, C., \& Hatfield, R. (2007). Child mortality and injury in Asia: An overview (Innocenti Working Paper 2007-04, Special Series on Child Injury No. 1). https://www.unicef-irc.org/publications/480-child-mortality-and-injury-in-asia-an-overview.html

Linnan, M., Rahman, A., Scarr, J., Reinten-Reynolds, T., Linnan, H., Rui-Wei, J., Mashreky, S., Shafinaz, S., Bose, S., \& Finkelstein, E. (2012). Child drowning: Evidence for a newly recognized cause of child mortality in low and middle income countries in Asia (Working Paper 2012-07, Special Series on Child Injury No. 2). https:/www.unicef-irc.org/publications/663-child-drowning-evidence-for-a-newly-recognized-cause-ofchild-mortality-in-low-and.html

Marchant, E., Todd, C., Cooksey, R., Dredge, S., Jones, H., Reynolds, D., Stratton, G., Dwyer, R., Lyons, R., \& Brophy, S. (2019). Curriculum-based outdoor learning for children aged 9-11: A qualitative analysis of pupils' and teachers' views. PLoS One, 14(5), 1-241-24. https://doi.org/10.1371/journal.pone.0212242

NationalWater Safety Forum. (2019). 2018 UKWater Related Fatalities Published. https://www.nationalwatersafety. org.uk/news/posts/2019/april/2018-uk-water-related-fatalities-published/

Norwegian Directorate for Education and Training. (2019). Lereplan i kroppsøving (KRO01-05). https://www. udir.no/lk20/kro01-05

Norwegian Society for Sea Rescue. (2020). Drukningsoversikt. https:/www.redningsselskapet.no/drukning/

Norwegian Society for Sea Rescue \& Retriever. (2020). Drukningsstatistikk: Desember 2020. https://www. redningsselskapet.no/content/uploads/2021/01/Redningsselskapets-drukningsstatistikk-2020.pdf

Peden, M., Oyegbite, K., Ozanne-Smith, J., Hyder, A. A., Branche, C., Rahman, A., Rivara, F., \& Bartolomeos, K. (Eds.). (2008). World report on child injury prevention. World Health Organization. https://www.who.int/ publications/i/item/9789241563574

Postholm, M. B. (2019). Research and development in school: Grounded in cultural historical activity theory. Brill.

Rahman, F., Bose, S., Linnan, M., Rahman, A., Mashreky, S., Haaland, B., \& Finkelstein, E. (2012). Cost-effectiveness of an injury and drowning prevention program in Bangladesh. Pediatrics, 130(6), e1621-e1628. https://doi.org/10.1542/peds.2012-0757

Smith, J. A., Larkin, M., \& Flowers, P. (2009). Interpretative phenomenological analysis: Theory, method and research. Sage.

Stallman, R., Moran, K., Brenner, R., \& Rahman, A. (2013). Swimming and water survival competence. In J. Bierens (Ed.), Drowning (pp. 197-206). Springer. https://doi.org/10.1007/978-3-642-04253-9_30

Stallman, R. K., Moran, K., Quan, L., \& Langendorfer, S. (2017). From swimming skill to water competence: Towards a more inclusive drowning prevention future. International fournal of Aquatic Research and Education, 10(2), 1-35. https://doi.org/10.25035/ijare.10.02.03

Torre, D., \& Murphy, J. (2015). A different lens: Changing perspectives using photo-elicitation interviews. Education Policy Analysis Archives, 23, 111, 1-23. https://doi.org/10.14507/epaa.v23.2051 


\section{T. Lundhaug \& H. R. Eriksen}

Williams, A., \& Wainwright, N. (2020). Re-thinking adventurous activities in physical education: Models-based approaches. Fournal of Adventure Education and Outdoor Learning, 20(3), 217-229. https://doi.org/10.108 $0 / 14729679.2019 .1634599$

World Health Organization. (2006). Guidelines for safe recreational water environments: Volume 2, Swimming pools and similar environments. World Health Organization. https://apps.who.int/iris/handle/10665/43336

World Health Organization. (2017). Preventing drowning: An implementation guide. World Health Organization. https://www.who.int/publications/i/item/preventing-drowning-an-implementation-guide

Waagene, E., Vaagland, K., Larsen, E., \& Federici, R. A. (2018). Spørsmål til Skole-Norge:Analyser og resultater fra Utdanningsdirektoratets spørreundersøkelse til skoler og skoleeiere våren 2018. (NIFU-rapport 2018:19). https:// nifu.brage.unit.no/nifu-xmlui/handle/11250/2565301

Yang, L., Nong, Q.-Q., Li, C.-L., Feng, Q.-M., \& Lo, S. K. (2007). Risk factors for childhood drowning in rural regions of a developing country: A case-control study. Injury Prevention, 13(3), 178-182. https://doi. org/10.1136/ip.2006.013409 